\title{
Selective feeding in the hawksbill turtle, an important predator in coral reef ecosystems
}

\author{
Yolanda M. León*, Karen A. Bjorndal \\ Archie Carr Center for Sea Turtle Research and Department of Zoology, University of Florida, Gainesville, Florida 32611, USA
}

\begin{abstract}
We evaluated selective feeding in hawksbill turtles Eretmochelys imbricata by comparing ingested prey species with their availability at 2 sites in the SW Dominican Republic. Hawksbills fed on 6 benthic species: 5 demosponges (Chondrilla nucula, Geodia neptuni, Myriastra kalitetilla, Spirastrella coccinea, and Tethya crypta) and 1 corallimorpharian (Ricordea florida). Hawksbills showed positive selection for 4 species (from highest to lowest): S. coccinea, $R$. florida, and C. nucula at Bahía de las Aguilas, and M. kalitetilla and C. nucula at Cabo Rojo. S. coccinea and M. kalitetilla are rare in the environment and highly selected by hawksbills, which supports a previous observation that their distribution on reefs could be greatly affected by spongivores. The 2 remaining selected species were the dominant prey species in lavage samples ( $R$. florida $=59 \%$ and C. nucula $=$ $34 \%$ of total volume). Since they were the most abundant species at each site, this illustrates that diet choice is based on a combination of selectivity for certain species and local abundance. The dominance of $R$. florida in the diet challenges the prevailing view that Caribbean hawksbills are strict spongivores. Finally, our results indicate that hawksbills can have a positive indirect effect on corals by grazing on coral competitors, as well as affect overall reef benthic biodiversity. Both C. nucula and $R$. florida harbor photosynthesizing symbionts and are aggressive competitors for space on tropical reefs. Thus, at natural population levels, grazing by hawksbills may well have played an important role in Caribbean reef structure and dynamics. Because hawksbill populations have been substantially reduced (to at most $10 \%$ of pre-Columbian population levels) their effect has been considerably diminished.
\end{abstract}

KEY WORDS: Hawksbill turtle $\cdot$ Selective feeding $\cdot$ Sponges $\cdot$ Caribbean coral reefs $\cdot$ Indirect effects

\section{INTRODUCTION}

Juvenile and adult hawksbill turtles forage in a variety of coral and sponge reefs, reef walls, and other hard-bottom habitats throughout the tropics. Several studies of the diet of hawksbills in the Caribbean have established that they feed almost exclusively on sponges (Acevedo 1984, Meylan 1984, 1988, Vicente 1993, Anderes \& Uchida 1994, van Dam \& Diez 1997). Although over 300 species of sponges occur in the Caribbean, hawksbills select only a few species, which

${ }^{*}$ Present address: 310 Washburn Hall, Department of Marine Affairs, University of Rhode Island, Kingston, Rhode Island 02881, USA. Email: ymleon@yahoo.com vary somewhat among localities. Diet selection by hawksbills has not been evaluated relative to prey availability.

Sponges are abundant and conspicuous members of current Caribbean coral reef communities, where their biomass, diversity, and abundance often exceed those of corals (Goreau \& Hartman 1963, Rützler 1978, Suchanek et al. 1983, Targett \& Schmahl 1984). Predation on sponges has been compared to herbivory on plants (Chanas \& Pawlik 1996), because reef sponges are abundant, clonal, often autotrophic, lack behavioral responses (Arillo et al. 1993), and are non-fatally grazed by reef fish (Wulff 1994). However, despite these similarities with relatively well-studied plantherbivore systems, the relationship between spongi- 
vores and their prey as well as the resulting interactions within the coral reef community have scarcely been explored (but see Hill 1998, Pawlik 1998).

Numerous studies have documented the important impact of fish predation on the structure, ecology and evolution of the benthic invertebrate communities of coral reefs (Hixon 1983, Jones et al. 1991). Bakus $(1966,1983)$ suggested that fish predation is the major factor influencing the distribution, density, and productivity of coral reef invertebrates, thus maintaining the nonequilibrium state and high species diversity that characterize this ecosystem. Other studies have described effects on the invertebrate community that can be direct (resulting from fish-induced mortality) or indirect (caused by removal or cultivation of competitor species, as well as habitat disturbance [Suchanek \& Colin 1986, Glynn 1988]).

There is a growing awareness that pre-Columbian and early historic over-fishing by humans has had, and continues to have, drastic effects on marine ecosystems (Jackson et al. 2001). Efforts to model and restore past ecosystems such as 'back to the future' (Pitcher 2001) are stymied by our lack of knowledge about the roles in marine systems of major predators whose populations have been extirpated or greatly reduced over the past few centuries (Jackson 1997, 2001, Jackson et al. 2001).

The absence of hawksbills from many modern reefs has almost certainly changed reef dynamics. Adult Caribbean hawksbills weigh $60 \mathrm{~kg}$ on average (Bjorndal et al. 1985) and are by far the largest spongivores on coral reefs. As Jackson (1997) noted, small consumers (such as fish) cannot fully compensate for the loss of megavertebrates on reefs because they do not consume or process prey in the same way as larger species. Based on levels of harvest and population trends reviewed in Meylan \& Donnelly (1999) and Parsons (1972), current hawksbill populations in the Caribbean represent at most $10 \%$ of pre-Columbian levels. At earlier population levels, hawksbill foraging would have influenced reef community structure to a greater extent. Theories of how predation affects coral reef habitats probably suffer from the 'shifting baseline syndrome' (Pauly 1995). Most ecological studies on coral reefs have been conducted long after large vertebrates became extinct or decimated in the Caribbean (Jackson 1997). As a result, researchers have perhaps over-emphasized the roles of fishes and invertebrates, because these species constitute the only abundant predators on most coral reefs today. Evaluation of diet selection in hawksbills would yield important insights into the effects of this major predator in the coral reef ecosystem.

We conducted a study of diet selectivity in hawksbills at 2 sites in the SW Dominican Republic by comparing the abundance of items in their diet and their environment. Our objectives were to (1) determine whether hawksbills feed selectively, (2) identify prey species for which there was positive selection, and (3) evaluate potential effects of hawksbill foraging on reef ecosystems.

\section{MATERIALS AND METHODS}

Turtle surveys. We selected 2 coral reef sites in the SW Dominican Republic $\left(17^{\circ} 55^{\prime} \mathrm{N}, 71^{\circ} 40^{\prime} \mathrm{W}\right)$, where juvenile hawksbills are common (León \& Diez 1999): Bahía de las Aguilas (Bahía, $1.52 \mathrm{~km}^{2}$ ) and Cabo Rojo (4.02 km $\mathrm{km}^{2}$ [Fig. 1]). Both sites have a maximum depth of approximately $20 \mathrm{~m}$ and are comprised of a diverse hard-bottom community, with a biota dominated by sponges, stony corals, hydrocorals, gorgonians and algae. A more detailed description of these reefs is presented elsewhere (León 2000). These 2 sites were selected from a number of sites studied in the area by León \& Diez (1999) because of the abundance of hawksbills and because Bahía has a higher coral cover than Cabo Rojo. We hoped that by studying 2 different reef types, we would be better able to detect general trends in feeding selectivity. A 3 yr mark-recapture study had already established that the turtles remained in the sites and did not move between them (León \& Diez 1999), indicating that animals sampled at each site were also most likely feeding there.

We captured turtles by hand during daytime snorkeling surveys. We collected diet samples by esophageal lavage, using a technique adapted from Balazs (1980). To identify sponges in the lavage samples, after sorting them according to external appearance, we dissolved a small (approximately $0.5 \mathrm{~cm}^{3}$ ) piece of sponge in a sodium hypochlorite solution and viewed the spicules under a light microscope using 100 to $400 \times$ magnification. The only non-sponge component in the lavage samples, the cnidarian Ricordea florida, was identified by voucher specimens sent to S. Cairns (National Museum of Natural History, Smithsonian Institution, pers. comm. 1997). For each prey species in each lavage sample, we measured volume by water displacement and wet mass after removing surface water by blotting with absorbent towels.

For nutrient content of prey species we relied on values in the literature. Because no data were available for Ricordea florida, we analyzed a sample from our study area for organic matter (ash-free dry matter) in a muffle furnace at $500^{\circ} \mathrm{C}$ in a standard Parr bomb calorimeter with fuse wire and acid corrections, and nitrogen and carbon in a Carlo Erba elemental analyzer.

Benthic surveys. Ten days after most of the lavage samples were collected, we surveyed the benthos of the study sites using belt transects stratified by depth to quantify the amounts of prey species available to the 


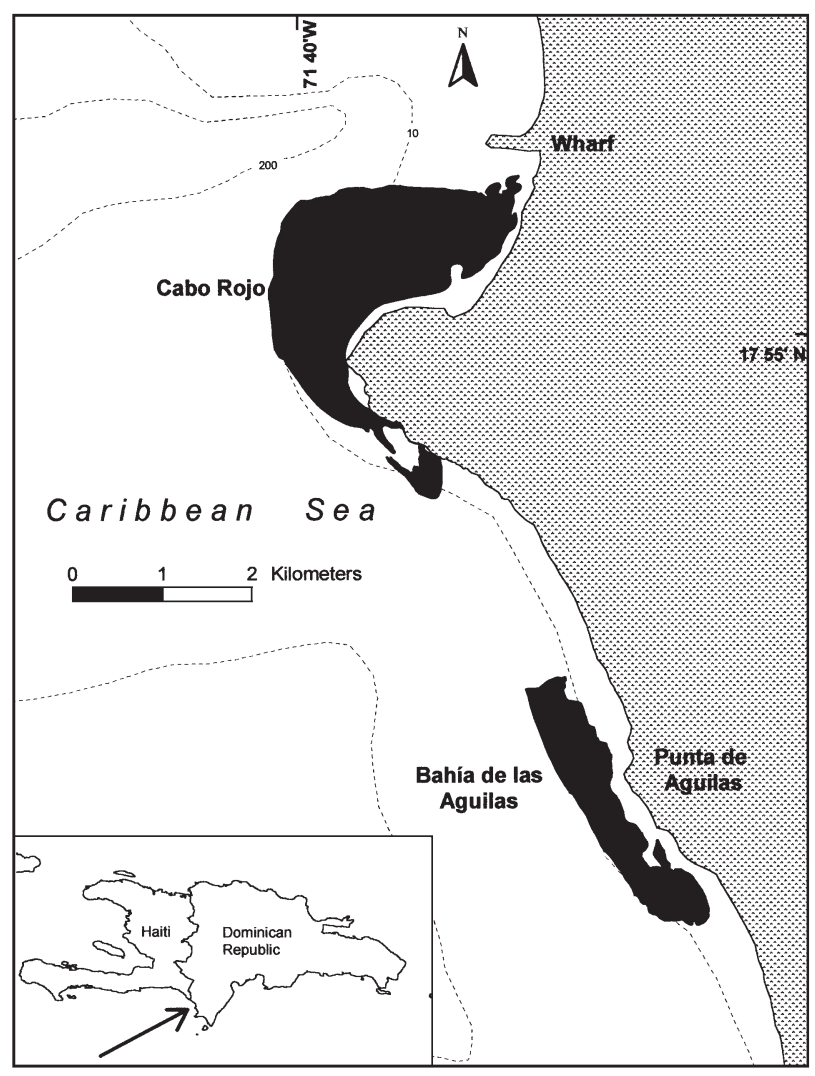

Fig. 1. Location of study sites, Bahía de las Aguilas and Cabo Rojo. Isobath lines show water depth in meters

turtles. Personal observations (Y.M.L.) indicated that there were faunal differences related to depth in the study area, but turtles from every size class had been seen foraging in all depth zones (León \& Diez 1999). Therefore, we decided to stratify our field sampling by depth. First, we defined 4 depth zones $(5,10,15 \& 20 \mathrm{~m})$ by plotting depth soundings conducted every $500 \mathrm{~m}$ along transects perpendicular to the shore separated by $1 \mathrm{~km}$. We used Arcview's GIS Spatial Analyst software (ESRI) to produce a map of the depth zones by interpolation of the soundings. Next, we distributed the total number of transects in proportion to the reef extent at each depth zone within each site.

To conduct the transects, we placed a $10 \mathrm{~m}$ line along the reef formations. The transect locations were chosen by navigating to random coordinates on the reef until the quota number of transects for each depth zone was reached. Once in the transect location, 10 consecutive quadrats of $1 \mathrm{~m}^{2}$ were laid in the center of the transect line. Within the area defined by each quadrat, we conducted an extensive search for all prey species and scored their abundance.

To quantify abundance of massive sponges, we measured the 3 axes of each specimen in situ (Reiswig 1973) with a plastic ruler, and calculated their volume and surface area by approximating their geometric shape (sphere or cylinder). We estimated the surface area of encrusting sponges and cnidarians by placing a grid of $5 \mathrm{~cm}^{2}$ squares over the specimen, positioning the grid in different planes to cover the entire organism or colony. We used a value of $0.2 \mathrm{~cm}$ thickness, based on field observations, to calculate the volume of these encrusting forms.

Data analysis. We used 3 measures of selectivity to evaluate diet selection in hawksbills: Ivlev's electivity index (Ivlev 1961), Manly-Chesson's standardized index (Manly et al. 1972, Chesson 1978), and a chisquare goodness-of-fit analysis to test the hypothesis that prey ingestion occurred in proportion to availability (Neu et al. 1974, Byers et al. 1984). Because we could only estimate the proportion of available prey species, we used the modified form of the chi-square statistic recommended by Manly et al. (1993) for such cases. When the chi-square test was significant, we proceeded to test a second hypothesis that ingestion occurred in proportion to availability considering each prey species separately. To do this, we computed simultaneous Bonferroni 95\% confidence limits for proportions of the prey species consumed $\left(O_{i}\right)$ and compared these with the estimated available proportions in the environment $\left(\pi_{i}\right)$ (Neu et al. 1974, Byers et al. 1984). Selection (positive or negative) for that prey species is indicated if $\pi_{i}$ falls outside the confidence interval calculated for $O_{i}$.

\section{RESULTS}

\section{Diet composition}

Between May and July 1999, we performed 56 esophageal lavages on hawksbills, 48 of which yielded diet samples. Turtles sampled were immature and ranged in size from 18.5 to $50.1 \mathrm{~cm}$ straight carapace length $($ mean $=34.1, \mathrm{SD}=7.9)$. Samples contained from 1 to 3 prey species (mean $=1.25, \mathrm{SD}=0.49$ ). No significant relationship was detected between turtle size and volume (in $\mathrm{ml}$ ) of lavage sample $\left(\mathrm{r}^{2}=0.013, \mathrm{p}=0.41\right.$ ).

Lavage samples for the 2 sites contained a total of 6 invertebrate species: the sponges Chondrilla nucula, Geodia neptuni, Myriastra kalitetilla, Spirastrella coccinea, Tethya crypta, and the corallimorpharian Ricordea florida (Table 1). Other components in the lavage samples included fragments of various brown and red algae, such as Dyctiota spp. and Hypnea sp., as well as small pieces of inert material (i.e. rock and shell fragments). However, these particles were present in very small quantities $(<0.01 \%$ of wet mass for both sites combined). We also found some sponge fragments that could not be identified because no diag- 
nostic spicules were detected, but these accounted for a small portion of the samples $(<0.01 \%$ of total wet mass). Thus, we excluded non-identified sponges, algae, and inert material from subsequent analyses.

At both sites, there were significant differences in volume of prey species present in the lavages (Friedman test, lavages serving as blocks: Friedman statistic = 34.6, $\mathrm{n}=26, \mathrm{p}<0.0001$ for Bahía, and Friedman statistic $=12.9, \mathrm{n}=22, \mathrm{p}=0.005$ for Cabo Rojo). The lavage samples from Bahía yielded 5 prey species, dominated by Chondrilla nucula (59\% of volume) and Ricordea florida (32\%). In Cabo Rojo, only 4 prey species were found, and the same pair of species predominated in the lavage samples. However, in Cabo Rojo, $R$. florida had the highest percent contribution to the total volume ( $81 \%$ ) followed by C. nucula (14\%).

Composition of Ricordea florida on a dry mass basis was $53.3 \%$ organic matter, $3.5 \%$ nitrogen, $26.5 \%$ carbon, and $12.1 \mathrm{~kJ} \mathrm{~g}^{-1}$. Energy content on an ash-free dry mass basis was $22.8 \mathrm{~kJ} \mathrm{~g}^{-1}$.

\section{Prey species availability}

A total of $810 \mathrm{~m}^{2}$ was sampled for prey availability. Transects at Bahía and Cabo Rojo detected all prey species present in the lavage samples, except for Geodia neptuni at Cabo Rojo, which was also absent from the lavage samples there (Table 2). There were significant differences in the area occupied by species (Friedman test, 1 at each site, transects serving as blocks; Friedman statistic $=70.15, \mathrm{n}=34, \mathrm{p}<0.0001$ in Bahía, and Friedman statistic $=113.87, \mathrm{n}=47$, $\mathrm{p}<0.0001$ in Cabo Rojo). At both sites, Chondrilla nucula, Ricordea florida, and Tethya crypta were the most abundant species.
The relative contributions calculated from volume were considerably different from those using area measurements due to the disproportionately greater volume that massive sponges have relative to encrusting organisms. A large portion of the total volume resulted from only 3 individuals of Geodia neptuni at Bahía. We decided to use area measurements for subsequent analyses and discussion, because greater area contributions are assigned to the primary prey species, which are encrusting forms, therefore making our selectivity analyses more conservative.

\section{Diet selectivity}

Prey species were selected in different proportions than would be predicted from their abundance in the environment (Fig. 2). Ingestion did not occur in proportion to availability when all species were analyzed together $\left(\chi^{2}{ }_{5}=536.18, \mathrm{p}<0.001\right.$ at Bahía and $\chi_{4}^{2}=126.39$, $\mathrm{p}<0.001$ at Cabo Rojo). The evaluation of individual prey species by comparing the confidence limits of ingested proportions with the available proportions and their electivity index values indicated positive selection for Spirastrella coccinea, Ricordea florida, and Chondrilla nucula at Bahía and positive selection for Myiastra kalitetilla and C. nucula at Cabo Rojo (Table 3). In addition, at Bahía, the electivity index indicated positive selection for $M$. kalitetilla. It is possible that the rarity of this sponge could have caused its small contribution to the lavages at Bahía, thus affecting the selectivity measurements. This is supported by the standardized index $\left(B_{i}\right)$ value for $M$. kalitetilla. This measure attempts to correct for broad differences in availability and the value falls within the range of selected species at Bahía. Similarly, the scarcity of $S$.

Table 1. Summary of lavage samples by site (Bahía $n=26$, Cabo Rojo $n=22$ ). Percent occurrence is \% of lavage samples in which the prey species occurred

\begin{tabular}{|c|c|c|c|c|c|c|c|c|c|c|}
\hline \multirow{3}{*}{ Species } & \multirow{3}{*}{$\begin{array}{c}\% \\
\text { Occur- } \\
\text { rence }\end{array}$} & \multirow{2}{*}{\multicolumn{2}{|c|}{$\begin{array}{l}\text { Bahía- } \\
\text { Wet mass }\end{array}$}} & \multirow{2}{*}{\multicolumn{2}{|c|}{ Volume }} & \multirow{3}{*}{$\begin{array}{c}\% \\
\text { Occur- } \\
\text { rence }\end{array}$} & \multirow{2}{*}{\multicolumn{2}{|c|}{$\begin{array}{l}\text { Cabo Rojo } \\
\text { Wet mass }\end{array}$}} & \multirow{2}{*}{\multicolumn{2}{|c|}{ Volume }} \\
\hline & & & & & & & & & & \\
\hline & & $\begin{array}{l}\text { Total } \\
\text { (g) }\end{array}$ & $\begin{array}{l}\text { Individual } \\
\text { mean (SD) }\end{array}$ & $\begin{array}{l}\text { Total } \\
(\mathrm{ml})\end{array}$ & $\begin{array}{l}\text { Individual } \\
\text { mean (SD) }\end{array}$ & & $\begin{array}{l}\text { Total } \\
\text { (g) }\end{array}$ & $\begin{array}{l}\text { Individual } \\
\text { mean (SD) }\end{array}$ & $\begin{array}{l}\text { Total } \\
(\mathrm{ml})\end{array}$ & $\begin{array}{l}\text { Individual } \\
\text { mean (SD) }\end{array}$ \\
\hline \multicolumn{11}{|l|}{ Phylum Porifera } \\
\hline \multicolumn{11}{|l|}{ Order Choristida } \\
\hline Chondrilla nucula & 73.1 & 19.3 & $0.74(1.09)$ & 17.5 & $0.67(0.96)$ & 40.9 & 6.0 & $0.28(0.61)$ & 4.9 & $0.22(0.50)$ \\
\hline Geodia neptuni & 15.4 & 0.6 & $0.02(0.07)$ & 0.6 & $0.02(0.06)$ & - & - & - & - & - \\
\hline Myriastra kalitetilla & 3.9 & 1.5 & $0.06(0.29)$ & 1.5 & $0.06(0.29)$ & 13.6 & 0.8 & $0.04(0.12)$ & 0.9 & $0.04(0.12)$ \\
\hline \multicolumn{11}{|l|}{ Order Hadromerida } \\
\hline Spirastrella coccinea & 11.5 & 0.8 & $0.03(0.12)$ & 0.7 & $0.03(0.12)$ & - & - & - & - & - \\
\hline Tethya crypta & - & - & - & - & - & 4.5 & 0.8 & $0.04(0.17)$ & 0.8 & $0.04(0.17)$ \\
\hline \multicolumn{11}{|l|}{ Phylum Cnidaria } \\
\hline \multicolumn{11}{|l|}{ Order Corallimorpharia } \\
\hline Ricordea florida & 26.9 & 10.0 & $0.38(0.80)$ & 9.6 & $0.37(0.78)$ & 63.6 & 28.4 & $1.35(3.75)$ & 28.7 & $1.30(3.88)$ \\
\hline Total & & 32.2 & & 29.9 & & & 36.0 & & 35.3 & \\
\hline
\end{tabular}


Table 2. Mean area and volume estimates per transect for the identified prey species at the 2 study sites; standard deviation in parentheses. Percentages represent percent contribution to the total estimated area or volume of prey species. Species with the same group letter are not significantly different in area rank totals per transect (Fisher's least significant difference, overall $\alpha=0.1$ )

\begin{tabular}{|c|c|c|c|c|c|c|c|c|c|c|}
\hline & \multicolumn{5}{|c|}{ - Bahía } & \multicolumn{5}{|c|}{ - Cabo Rojo - } \\
\hline & $\begin{array}{l}\text { Mean area } \\
\left(\mathrm{cm}^{2}\right)\end{array}$ & $\%$ & $\begin{array}{l}\text { Mean volume } \\
\qquad\left(\mathrm{cm}^{3}\right)\end{array}$ & $\%$ & Group & $\begin{array}{l}\text { Mean area } \\
\left(\mathrm{cm}^{2}\right)\end{array}$ & $\%$ & $\begin{array}{l}\text { Mean volume } \\
\qquad\left(\mathrm{cm}^{3}\right)\end{array}$ & $\%$ & Group \\
\hline Chondrilla nucula & $408.2(524.1)$ & 54.2 & $40.8(52.4)$ & 3.3 & $\mathrm{a}$ & $109.3(180.1)$ & 19.8 & $10.9(18.0)$ & 3.4 & a \\
\hline Ricordea florida & $46.4(77.0)$ & 6.2 & $4.6(7.7)$ & 0.4 & $a, b$ & 344.8 (1333.5) & 62.5 & $34.5(133.4)$ & 10.8 & $\mathrm{a}$ \\
\hline Tethya crypta & $128.0(232.5)$ & 17.0 & $384.0(697.4)$ & 31.0 & $a, b$ & $92.5(260.9)$ & 16.8 & $277.5(782.8)$ & 85.3 & $a, b$ \\
\hline Myriastra kalitetilla & $5.6(23.3)$ & 0.8 & $5.3(22.1)$ & 0.4 & $\mathrm{~b}$ & $1.7(11.5)$ & 0.3 & $2.9(13.7)$ & 0.4 & $\mathrm{~b}$ \\
\hline Spirastrella coccinea & $4.2(12.8)$ & 0.6 & $0.4(1.3)$ & 0.0 & $\mathrm{~b}$ & 3.7 (19.8) & 0.7 & $0.4(2.0)$ & 0.1 & $\mathrm{~b}$ \\
\hline Geodia neptuni & $160.1(762.4)$ & 21.3 & $803.3(4062.6)$ & 64.9 & $a, b$ & $0.0-$ & 0.0 & $0.0-$ & - & - \\
\hline
\end{tabular}

coccinea in the environment could explain its absence in the lavages at Cabo Rojo, thus excluding it from all positive selectivity values there.

\section{DISCUSSION}

\section{Diet composition: prey abundance and selectivity}

In the first diet study of Caribbean hawksbills, Carr \& Stancyk (1975) concluded that the hawksbill is a relatively indiscriminate feeder on benthic invertebrates. Subsequent studies with greater sample sizes at different localities in the Caribbean (Meylan 1988, Anderes \& Uchida 1994, van Dam \& Diez 1997) rejected this idea in favor of strict spongivory. However, the diet reported by Carr \& Stancyk (1975), of predominantly sponges and the tunicate Styella sp., resembles the mix of sponges and Ricordea florida in our study. In addition, a zoanthid

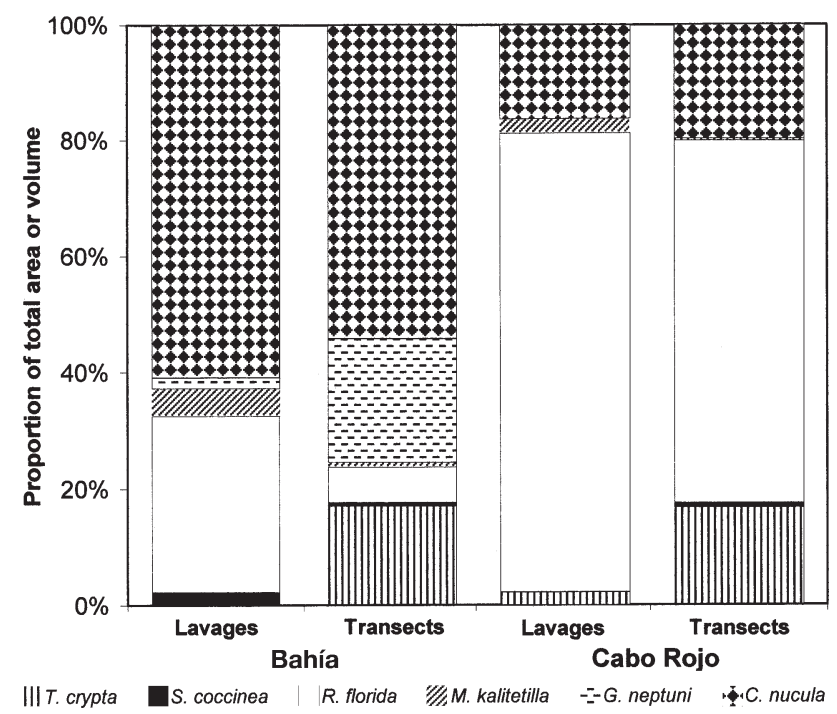

Fig. 2. Comparison of consumption proportions (from total volume in lavage samples) vs availability of food items (from total area in transect data) at the 2 study sites
(Zoanthus sociatus) was the main component of the hawksbill diet and occupied extensive areas of the benthos in the U.S. Virgin Islands (Mayor et al. 1998; Pemberton et al. 2000). Thus, hawksbills are not strict spongivores and can include in their diet substantial quantities of non-sponge invertebrates that may be abundant in their environment. In our study, however, sponges as a group were still the most frequent diet item, being present in $67 \%$ of the lavage samples.

Our results do not support the indiscriminate feeding pattern suggested by Carr \& Stancyk (1975) but indicate that the diet of the hawksbill is determined by a combination of selective feeding and abundance of prey species in the environment. For an organism to exhibit selective feeding, a variety of potential food items must be available in sufficient abundance to allow the animal a choice.

Several lines of evidence indicate that hawksbills in our study area had sufficient abundance of food to allow selective feeding. First, most prey species were relatively common in both study sites; even if in small amounts, at least 1 prey species was detected in all transects. Second, the limited movements shown by hawksbills in our study area (mean displacement between captures $=360 \mathrm{~m}, \mathrm{SD}=320 \mathrm{~m}$, range: 60 to $1550 \mathrm{~m}$, time interval: 45 to 571 d; León \& Diez 1999) indicate that they can meet their intake requirements in a relatively small area. Third, hawksbills in this study consumed a small number of species, suggesting high food abundance according to optimal foraging theory, which proposes that animals attempting to maximize their rate of energy intake will exhibit greater food specialization when confronted with food abundance (Pyke et al. 1977). An example consistent with this theory was detected in a comparison of hawksbills from a reef and from a cliff wall habitat. Hawksbills foraging on the cliff wall consumed fewer sponge species (3 vs 10), spent less time foraging, and grew significantly faster than did hawksbills foraging on the reef (van Dam \& Diez 1997), suggesting that food was more abundant on the cliff wall. 
Two prey species clearly dominated the lavage samples and available prey area estimates: Chondrilla nucula at Bahía (58\% of lavage volume, 54\% of prey area) and Ricordea florida at Cabo Rojo $(81 \%, 62 \%)$. However, abundance alone did not account for the prevalence of C. nucula and $R$. florida in the diet: both species were consumed disproportionately when compared to their abundance in the field. Furthermore, at each site, the species that was less abundant in the habitat was more highly selected (Table 3).

However, the above-described selectivity pattern seems to be obscured by the differential abundance of prey species. The other 2 species for which there was positive selection (Myriastra kalitetilla and Spirastrella coccinea) were rare at the study sites. The few individuals of $M$. kalitetilla observed during surveys were short $(\leq 7 \mathrm{~cm})$ compared with the maximum height of $15 \mathrm{~cm}$ (Wiedenmayer 1977). Similarly, S. coccinea was found as small individuals encrusted in vertical faces of rocks or coral heads. One of the lavage samples in Bahía contained a volume of $S$. coccinea that suggested the entire specimen was consumed at once, based on the size of the few $S$. coccinea individuals seen in the field. The fact that $S$. coccinea was highly selected at Bahía, but not found in the lavage samples at Cabo Rojo, can be attributed to its rarity; we only found 3 small individuals in 2 of the 48 transects conducted at Cabo Rojo.

\section{Criteria for prey selection}

All sponge prey species identified in this study have been previously reported in at least 1 study of hawksbill diets in the Caribbean, except for Spirastrella Coccinea. The affinity of hawksbills throughout the region for a relatively small number of sponges is remarkable given the diversity of sponge species in their habitat (over 300 sponge species are known from the Caribbean) and highlights the importance of these sponge species for hawksbills. All of the sponge prey species in our study are also eaten by spongivorous fish. Two of the prey sponges in our study ranked second (Chondrilla nucula found in 20 guts and in 7 cases the most abundant species in the gut) and third $(S$. coccinea, 19,6) in frequency and percent volume in 144 guts of butterfly-, angel- and filefishes (Randall \& Hartman 1968). S. coccinea also ranked second in 70 sponge-feeding observations of angelfishes (genus Pomacanthus; Wulff 1994).

Thus, hawksbills may be using certain criteria in selecting their prey throughout the region, such as abundance (discussed above), nutrient content, or presence of chemical defenses. Sponges consumed in this study have higher nutrient content than many other sponges, especially in terms of protein (Chanas \& Pawlik 1995), except for Spirastrella coccinea. Chondrilla nucula ranked 8 in protein content out of 71

Table 3. Three measures of diet selectivity for prey species. If the relative abundance (area covered) in the environment $\left(\pi_{i}\right)$ falls outside the Bonferroni $95 \%$ confidence interval for lavage sample proportion $\left(O_{i}\right)$, then there is selectivity (positive or negative) for that prey species. Electivity index $\left(E_{i}\right)$ and Standardized index $\left(B_{i}\right)$ are also shown. Selectivity denotes positively selected species, defined here as having a lower proportion in the environment than in the lavages $\left(\pi_{i}<95 \%\right.$ CI for $\left.O_{i}\right)$ and an electivity index $\left(E_{i}\right)$ value greater than zero

\begin{tabular}{|c|c|c|c|c|c|c|}
\hline Prey species & $\pi_{i}$ & $\begin{array}{r}95^{\circ} \\
\text { Lower }\end{array}$ & ${ }^{\nu_{i}}$ Upper & $E_{i}^{\mathrm{a}}$ & $B_{i}^{\mathrm{b}}$ & Selectivity \\
\hline \multicolumn{7}{|l|}{ Bahía } \\
\hline Chondrilla nucula & 0.54 & 0.62 & 0.72 & 0.10 & 0.09 & + \\
\hline Geodia neptuni & 0.21 & 0.00 & 0.03 & -0.84 & 0.01 & \\
\hline Myriastra kalitetilla & 0.01 & 0.00 & 0.03 & 0.36 & 0.15 & \\
\hline Ricordea florida & 0.06 & 0.21 & 0.30 & 0.62 & 0.29 & + \\
\hline Spirastrella coccinea & 0.01 & 0.02 & 0.06 & 0.74 & 0.47 & + \\
\hline Tethya crypta & 0.17 & 0.00 & 0.00 & -1.00 & 0.00 & \\
\hline Total & 1.00 & & & & 1.00 & \\
\hline \multicolumn{7}{|l|}{ Cabo Rojo } \\
\hline Chondrilla nucula & 0.20 & 0.21 & 0.32 & 0.25 & 0.11 & + \\
\hline Geodia neptuni & 0.00 & & & - & - & \\
\hline Myriastra kalitetilla & 0.00 & 0.01 & 0.05 & 0.95 & 0.80 & + \\
\hline Ricordea florida & 0.62 & 0.63 & 0.75 & -0.09 & 0.09 & \\
\hline Spirastrella coccinea & 0.01 & 0.00 & 0.00 & -1.00 & 0.00 & \\
\hline Tethya crypta & 0.17 & 0.00 & 0.03 & -0.64 & 0.01 & \\
\hline Total & 1.00 & & & & 1.00 & \\
\hline
\end{tabular}


Caribbean sponge species tested (Chanas \& Pawlik 1995). Nutrient and energy content of Ricordea florida is as high or higher than those of the prey sponges in our study. However, interpreting diet selection on the basis of nutrient content must be done with caution because concentration of a nutrient does not necessarily correspond to its availability. For example, collagen fibrils are a major source of protein in some sponges (Meylan 1985) that may have limited availability to hawksbills. Green turtles Chelonia mydas have a low digestibility of nitrogen from $C$. nucula, perhaps because of incomplete digestion of the collagen fibrils (Bjorndal 1990).

Sponges can contain chemical defenses known to deter predators. Extracts from 47 of 71 species of Caribbean demosponges were shown to deter fish consistently, whereas others were consistently palatable (Pawlik et al. 1995). Field observations corroborated that spongivorous fishes feed predominantly on chemically undefended sponge species (Dunlap \& Pawlik 1996). Also, chemical defenses of Caribbean demosponges are effective against hermit crabs and sea stars (Waddell \& Pawlik 2000a,b). These chemical defenses may affect hawksbill selection, but results of our study do not indicate a strong influence. Among the few sponge species that consistently yielded the most palatable extracts for fish (Pawlik et al. 1995) were Geodia neptuni, G. gibberosa, Chondrosia collectrix, Myriastra kalitetilla, C. reniformis, Spheciospongia vesparium, Iotrochota birotulata, and Niphates erecta. Even though all of these species are known to be consumed by hawksbills, and most were detected in our study area (except for C. collectrix and C. reniformis), only 2 (G. neptuni and M. kalitetilla) were found in the lavage samples; and no positive selectivity was shown for one of them (G. neptuni). In addition, extracts from the other 2 sponge prey species with positive selectivity in our study (Chondrilla nucula and Spirastrella coccinea) had low palatability for fish (Pawlik et al. 1995). However, it should be noted that C. nucula was one of the few species that exhibited considerable variation in chemical defense in the survey by Pawlik et al. (1995).

Sponge spicules (needle-like siliceous structures) have long been thought to play a role in defending demosponges against predators (Hartman 1981, Randall \& Hartman 1968). However, the role of spicules in predator deterrence is not clear. In experimental assays using generalist fishes, hermit crabs, and sea stars, no deterrence was found for species rich in spicules, as long as they were not chemically defended (Chanas \& Pawlik 1995, Waddell \& Pawlik $2000 a, b)$. Sponges that are important in hawksbill diets vary widely in spicule content ( 5 to $67 \%$ of dry mass; Meylan 1984). In our study, the lack of positive selec- tivity for Geodia neptuni (52 to 67\%) and Tethya crypta (no spicule data for T. crypta; $T$. aurantia = $33 \%$ ), and positive selectivity for Ricordea florida (0\%), Chondrilla nucula (5\%), and Myriastra kalitetilla $(21 \%)$ suggest that spicules may influence the diet selection of hawksbills when low-spicule items are abundant. Inspection of digestive tracts from wild hawksbills revealed large numbers of spicules embedded in the gut tissue and no apparent adaptation to decrease this penetration (Meylan 1988), which must irritate the tissue. Positive selectivity for $R$. florida may result not only from its high nutrient content and absence of spicules, but also because $R$. florida secretes large quantities of mucus when disturbed (authors' pers. obs.). Randall (1963) suggested that spongivorous fish may ingest cnidarians for their mucus, which could protect the alimentary track from abrasion by sponge spicules.

Low nutritional quality and chemical defenses can act together to deter predators (Duffy \& Paul 1992, Pennings et al. 1994). This combination may explain why certain sponges reported as prey species of Caribbean hawksbills in other studies were not present in our lavage samples, even though some were common in the study area, such as Cinachyrella kuekenthali, Ectyoplasia ferox, Niphates digitalis, $N$. erecta, Iotrochota birotulata, and Aplysina fistularis. Avoidance of these species may have resulted from the presence of less chemically defended and/or more nutritious sponges.

In summary, there are clear trends in the criteria for prey selection by hawksbills, but they are not entirely consistent. Selection for Chondrilla nucula may result from its great abundance, high nutrient and energy content, and low spicule content. Selection for Ricordea florida may result from high abundance, high nutrient and energy content, absence of spicules, and presence of protective mucus. Selectivity was greatest for Myriastra kalitetilla, which was rare in the study sites and had low chemical defenses and a moderate spicule concentration. The fact that Spirastrella coccinea, which has low nutrient content and high chemical defenses, was positively selected in our study and ranked high in fish trials (Randall \& Hartman 1968, Wulff 1994), may indicate that this sponge possesses a critical nutrient sought by hawksbills and fishes.

The 2 species Tethya crypta and Geodia neptuni, for which hawksbills did not show positive selectivity, have both been reported in other hawksbill diet studies and were abundant at 1 or both study sites. The availability of other prey easier to ingest and process may explain this. T. crypta has a higher level of chemical defense than other prey commonly found at both study sites. Tissues of $G$. neptuni are very tough (Chanas \& Pawlik 1995), and its surface is covered with 
a thick layer of spheroidal siliceous spicules (Randall \& Hartman 1968).

\section{Role of hawksbills in coral reef ecosystems}

Predation by hawksbills can affect diversity and structure of coral reef ecosystems by 3 different mechanisms:

(1) By selectively consuming prey sponges and cnidarians (as shown in this study) hawksbills do not simply crop prey species in proportion to their abundance. Instead, it seems that hawksbills can reduce highly selected prey to low levels and restrict them to refugia within the reef. We believe that high selectivity for the sponges Spirastrella coccinea and Myriastra kalitetilla in our study area was responsible for their rarity in the environment. In addition, Chondrosia collectrix, a common sponge in hawksbill diets, may be restricted to cryptic locations under coral rubble because of high predation (Pawlik 1998).

(2) Hawksbills can indirectly affect coral reef diversity by making prey species more vulnerable to predation by other organisms. Even though high population levels of hawksbills would increase competition with spongivorous fish and invertebrates, because these spongivores tend to select the same species (Randall \& Hartman 1968, Wulff 1994), hawksbills could make some prey sponges more available to fish by exposing the soft inner sponge tissues and endosymbionts after breaking through the tough outer layer (Meylan 1988).

(3) Hawksbills can also affect reef diversity and succession indirectly by influencing space competition. Scleractinian corals and sponges commonly compete for space on reefs with up to 12 interactions per square meter (Suchanek et al. 1983, Vicente 1990, Aerts \& van Soest 1997, Aerts 1998, Hill 1998). There is evidence that sponges are the superior competitor in $80 \%$ of such encounters (Suchanek et al. 1983, Vicente 1990). Bryan (1973) documented extensive takeover of a section of reef in Guam by an encrusting Terpios sponge (see also Plucer-Rosario 1987), and some sponges have been demonstrated to kill corals upon indirect contact, through waterborne metabolites (Porter \& Targett 1988). Also, there is evidence of competition for space between sponges and other benthic invertebrates (including other sponge species) through allelopathic interaction (Thacker et al. 1998, Engel \& Pawlik 2000). Thus, predation by hawksbills could have a major role in maintaining species diversity on coral reefs.

The dominance of Chondrilla nucula and Ricordea florida in the diet of hawksbills in our study and others (C. nucula was consumed by hawksbills in 7 of the 8 studies in the Caribbean, and, in most cases, made a major contribution to their diet) underscores the poten- tial role of hawksbills in space competition on coral reefs. Both $C$. nucula and $R$. florida are aggressive competitors for space with reef corals. C. nucula, $R$. florida, and scleractinian corals require open hard substrate for attachment of recruits and growth, and they require relatively shallow, well-lit areas where their autotrophic symbiotic cyanobacteria (C. nucula; Wilkinson \& Vacelet 1979) and zooxanthellae (scleractinian corals and $R$. florida; den Hartog 1980) can photosynthesize.

Chondrilla nucula is a very common Caribbean demosponge. It was the dominant sponge at $13 \%$ of shallow reef sites (depth $<7 \mathrm{~m}$ ) sampled off Cuba (Alcolado 1994), occupied up to $12 \%$ of the space in some Puerto Rican reef sites (Corredor et al. 1988), and was one of the dominant sponges in the Exuma Cays, Bahamas (Sluka et al. 1996). C. nucula was involved in nearly half of all scleractinian coral competitive interactions on a reef in Puerto Rico (Vicente 1990), caused $>70 \%$ of all coral overgrowths in a study in the Florida Keys (Hill 1998), and was considered one of the major threats to corals in a reef in Belize (Antonius \& Ballesteros 1998). Hill (1998) excluded sponge predators from coral/sponge interactions and concluded that indirect effects arising from spongivory may have large community effects in coral reefs because in the absence of spongivory, $C$. nucula would rapidly overgrow the majority of corals with which it interacts. None of the corals examined by Hill (1998) could compete with the rapid growth rates of $C$. nucula. Although not quantified, interactions of $C$. nucula with corals were commonly observed in our study area. Vicente (1990) documented aggressive competition for space by Ricordea florida at a Puerto Rican reef. In the Red Sea, a closely related species, the corallimorpharian Rhodactis rhodostoma, damages and overgrows a variety of sessile competitors, including scleractinian corals (Langmead \& Chadwick-Furman 1999).

Despite this intense competition experienced by scleractinian corals, relatively high coral cover on some modern Caribbean reefs indicates that sponges and other competitors are somehow prevented from overwhelming the corals. In the absence or nearabsence of hawksbills, predation by spongivorous fish, especially parrotfish (Dunlap \& Pawlik 1996, 1998, Wulff 1997, 2000, Hill 1998), and invertebrates has apparently fulfilled this role. Redundancy in ecosystems can mask the effect of species removal until all species performing a given function are lost (Jackson et al. 2001). As humans 'fish down the food web' (Dayton et al. 1998, Pauly et al. 1998), and parrotfish and other spongivorous fishes are overfished, the role of all sponge predators in maintaining the structure and function of coral reef ecosystems may become more apparent. 
We conclude that predation by hawksbills may have played an important role in the evolution and maintenance of Caribbean reef structure and dynamics, a role that has been overlooked because hawksbill populations have been decimated. Therefore, the hawksbill should be integrated into efforts to model trophic interactions and to restore and manage coral reef ecosystems. Recovery goals for hawksbill populations should be tied to restoring their past ecological roles, and selection of protected areas intended to benefit hawksbills should consider the patterns of selective feeding revealed in this study.

Acknowledgements. Funding for this project was provided by the Japan Bekko Association. Ideal Dominicana and Grupo Jaragua provided essential logistical support. We thank C. Diez and A. Bolten for their invaluable help in this project and C. Chapman and T. Frazer for advice on the design of this study. Many thanks to C. González, C. Pérez, W. Pérez, J. Ledesma, J. Mateo, I. Cabrera, J. A. Félix and E. Garrido for their assistance with field work and logistics in the study area. K. Moran and $\mathrm{S}$. Bouchard provided assistance with nutrient analysis.

\section{LITERATURE CITED}

Acevedo M (1984) Alimentación de tres especies de quelonios marinos en la plataforma suroccidental de Cuba. Rev Invest Mar 5:29-35

Aerts LAM (1998) Sponge/coral interactions in Caribbean reefs: analysis of overgrowth patterns in relation to species identity and cover. Mar Ecol Prog Ser 175:241-249

Aerts LAM, van Soest RWM (1997) Quantification of coral/ sponge interactions in a physically stressed reef community, NE Colombia. Mar Ecol Prog Ser 148:125-134

Alcolado P (1994) General trends in coral reef sponge communities of Cuba. In: van Soest RWM, van Kempen TMG, Braekman JC (eds) Sponges in time and space. AA Balkema, Rotterdam, p 251-255

Anderes BL, Uchida I (1994) Study of hawksbill turtle (Eretmochelys imbricata) stomach contents in Cuban waters. In: Study of the hawksbill turtle in Cuba (I). Ministry of Fishing Industry, La Habana, Cuba, p 27-40

Antonius A, Ballesteros E (1998) Epizoism: a new threat to coral health in Caribbean reefs. Rev Biol Trop 46(Suppl 5): 145-156

Arillo A, Bavestrello G, Burlando B, Sarà M (1993) Metabolic integration between symbiotic cyanobacteria and sponges: a possible mechanism. Mar Biol 117:159-162

Bakus GJ (1966) Some relationships of fishes to benthic organisms on coral reefs. Nature 210:280-284

Bakus GJ (1983) The role of fishes in the structuring of coral reef communities. Proc Int Conf Marine Sci in the Red Sea. Bull Egyptian Inst Oceanogr Fisheries 9:186-192

Balazs GH (1980) Field methods for sampling the dietary components of green turtles Chelonia mydas. Herp Rev 11:5-6

Bjorndal KA (1990) Digestibility of the sponge Chondrilla nucula in the green turtle, Chelonia mydas. Bull Mar Sci 47:567-570

Bjorndal KA, Carr A, Meylan AB, Mortimer JA (1985) Reproductive biology of the hawksbill Eretmochelys imbricata at Tortuguero, Costa Rica, with notes on the ecology of the species in the Caribbean. Biol Conserv 34:353-368
Bryan PG (1973) Growth rate, toxicity and distribution of the encrusting sponge Terpios sp. (Hadromerida: Suberitidae) in Guam, Mariana Islands. Micronesica 2:237-242

Byers CR, Steinhorst RK, Krausman PR (1984) Clarification of a technique for analysis of utilization-availability data. J Wildl Manage 48:1050-1053

Carr A, Stancyk S (1975) Observations on the ecology and survival outlook of the hawksbill turtle. Biol Conserv 8: 161-172

Chanas B, Pawlik JR (1995) Defenses of Caribbean sponges against predatory reef fish. II. Spicules, tissue toughness, and nutritional quality. Mar Ecol Prog Ser 127:195-211

Chanas B, Pawlik, JR (1996) Does the skeleton of a sponge provide defense against predatory reef fishes? Oecologia 107:225-231

Chesson J (1978) Measuring preference in selective predation. Ecology 59:211-215

Corredor JE, Wilkinson CR, Vicente VP, Morell JM, Otero E (1988) Nitrate release by Caribbean reef sponges. Limnol Oceanogr 33:114-120

Dayton P, Tegner M, Edwards P, Riser K (1998) Sliding baselines, ghosts, and reduced expectations in kelp forest communities. Ecol Appl 8:309-322

den Hartog JC (1980) Caribbean shallow water Corallimorpharia. Zoologische Verhandelingen 176. Rijksmuseum van Naturlijke Historie, Leiden

Duffy JE, Paul VJ (1992) Prey nutritional quality and the effectiveness of chemical defenses against tropical reef fishes. Oecologia 90:333-339

Dunlap M, Pawlik JR (1996) Video-monitored predation by Caribbean reef fishes on an array of mangrove and reef sponges. Mar Biol 126:117-123

Dunlap M, Pawlik JR (1998) Spongivory by parrotfish in Florida mangrove and reef habitats. Mar Ecol 19:325-337

Engel A, Pawlik JR (2000) Allelopathic activities of sponge extracts. Mar Ecol Prog Ser 207:273-281

Glynn PW (1988) Predation on coral reefs: some key processes, concepts and research directions. Proc 6th Int Coral Reef Symp 1:51-62

Goreau TF, Hartman WD (1963) Boring sponges as controlling factors in the formation and maintenance of coral reefs. In Sognnaes RF (ed) Mechanisms of hard tissue destruction. American Association for the Advancement of Science, New York, p 25-54

Hartman WD (1981) Form and distribution of silica in sponges. In: Simpson TL, Volcani BE (eds) Silicon and siliceous structures in biological systems. Springer-Verlag, New York, p 453-493

Hill M (1998) Spongivory on Caribbean reefs releases corals from competition with sponges. Oecologia 117:143-150

Hixon MA (1983) Fish grazing and community structure of reef corals and algae: a synthesis of recent studies. NOAA Sym Undersea Res 1:79-87

Ivlev VS (1961) Experimental ecology of the feeding of fishes. Yale University Press, New Haven, CT

Jackson JBC (1997) Reefs since Columbus. Coral Reefs 16 (Suppl):S23-S32

Jackson JBC (2001) What was natural in the coastal oceans? Proc Natl Acad Sci, USA 98:5411-5418

Jackson JBC, Kirby MX, Berger WH, Bjorndal KA and 15 others (2001) Historical overfishing and the recent collapse of coastal ecosystems. Science 293:629-638

Jones GP, Ferrell DJ, Sale PF (1991) Fish predation and its impact on the invertebrates of coral reefs and adjacent sediments. In: Sale PF (ed) The ecology of fishes on coral reefs. Academic Press, San Diego, p 156-179

Langmead O, Chadwick-Furman NE (1999) Marginal ten- 
tacles of the corallimorpharian Rhodactis rhodostoma. 1. Role in competition for space. Mar Biol 134:479-489

León YM (2000) Selective feeding in the hawksbill turtle: an important predator in coral reefs. MS thesis. University of Florida, Gainesville

León YM, Diez CE (1999) Population structure of hawksbill turtles on a foraging ground in the Dominican Republic. Chelonian Conserv Biol 3:230-236

Manly B, McDonald L, Thomas D (1993) Resource selection by animals: statistical design and analysis for field studies. Chapman \& Hall, London

Manly BFJ, Miller P, Cook LM (1972) Analysis of a selective predation experiment. Am Nat 106:719-736

Mayor PA, Phillips B, Hillis-Starr ZM (1998) Results of the stomach content analysis on the juvenile hawksbill turtles of Buck Island Reef National Monument, USVI. In: Epperly SP, Braun J (comp) Proc 17th Annual Sea Turtle Symp. NOAA Technical Memorandum NMFS-SEFSC-415, p 230-232

Meylan AB (1984) Feeding ecology of the hawksbill turtle (Eretmochelys imbricata): spongivory as a feeding niche in the coral reef community. PhD thesis, University of Florida, Gainesville

Meylan AB (1985) The role of sponge collagens in the diet of the hawksbill turtle (Eretmochelys imbricata). In: Vairati A, Garrone R (eds) Biology of invertebrate and lower vertebrate collagens. Plenum Press, New York, p 191-196

Meylan AB (1988) Spongivory of hawksbill turtles: a diet of glass. Science 239:393-395

Meylan AB, Donnelly M (1999) Status justification for listing the hawksbill turtle (Eretmochelys imbricata) as critically endangered on the 1996 IUCN Red List of Threatened Animals. Chelonian Conserv Biol 3:200-224

Neu CW, Byers CR, Peek JM (1974) A technique for analysis of utilization-availability data. J Wildl Manage 38:541-545

Parsons JJ (1972) The hawksbill turtle and the tortoiseshell trade. In: Études de géographie tropicale offertes a Pierre Gourou. Mouton, Paris, p 45-60

Pauly D (1995) Anecdotes and the shifting baseline syndrome of fisheries. Trends Ecol Evol 10:430-434

Pauly D, Christensen V, Dalsgaard J, Froese R, Torres F Jr (1998) Fishing down marine food webs. Science 279: 860-863

Pawlik JR (1998) Coral reef sponges: do predatory fishes affect their distribution? Limnol Oceanogr 43:1396-1399

Pawlik JR, Chanas B, Toonen RJ, Fenical W (1995) Defenses of Caribbean sponges against predatory reef fish. I. Chemical deterrency. Mar Ecol Prog Ser 127:183-194

Pemberton R, Coyne M, Musick JA, Phillips B, Hillis-Starr Z (2000) Habitat utilization of hawksbill sea turtles at Buck Island Reef National Monument: the zoanthid question. Proc 20th Ann Sym on Sea Turtle Biol and Conserv. NOAA Technical Memorandum

Pennings SC, Pablo SR, Paul VJ, Duffy JE (1994) Effects of sponge secondary metabolites in different diets on feeding by three groups of consumers. J Exp Mar Biol Ecol 119: 99-109

Pitcher TJ (2001) Fisheries managed to rebuild ecosystems? Reconstructing the past to salvage the future. Ecol Applic 11:601-617

Plucer-Rosario G (1987) The effect of substratum on the growth of Terpios, an encrusting sponge which kills corals. Coral Reefs 5:197-200

Porter JW, Targett NM (1988) Allelochemical interactions between sponges and corals. Biol Bull 175:230-239
Pyke GH, Pulliam HR, Charnov EL (1977) Optimal foraging: a selective review of the theory and tests. Q Rev Biol 52: $137-154$

Randall JE (1963) An analysis of the fish populations of artificial and natural reefs in the Virgin Islands. Caribb J Sci 3: $31-47$

Randall JE, Hartman WD (1968) Sponge feeding fishes of the West Indies. Mar Biol 1:216-225

Reiswig HM (1973) Population dynamics of three Jamaican Demospongiae. Bull Mar Sci 23:191-226

Rützler K (1978) Sponges in coral reefs. In: Stoddart DR, Johannes RF (eds) Coral reefs: research methods. Monographs on Oceanographic Methodologies (UNESCO) 5: 299-314

Sluka R, Chiappone M, Sullivan KM, Wright R (1996) Habitat and life in the Exuma Cays, the Bahamas. The Nature Conservancy, Arlington, VA

Suchanek TH, Colin PL (1986) Rates and effects of bioturbation by invertebrates and fishes at Enewetak and Bikini atolls. Bull Mar Sci 38:25-34

Suchanek TH, Carpenter RC, Witman JD, Harvell CD (1983) Sponges as important space competitors in deep Caribbean coral reef communities. NOAA Sym Series on Undersea Research 1:55-61

Targett NM, Schmahl GP (1984) Chemical ecology and distribution of sponges in the Salt River Canyon, St Croix, USVI. NOAA NMFS Tech Memo OAR NURP-1:1-60

Thacker RW, Becerro MA, Lumbang WA, Paul VJ (1998) Allelopathic interactions between sponges on a tropical reef. Ecology 79:1740-1750

van Dam RP, Diez CE (1997) Predation by hawksbill turtles on sponges at Mona Island, Puerto Rico. Proc 8th Int Coral Reef Symp 2:1421-1426

Vicente VP (1990) Overgrowth activity by the encrusting sponge Chondrilla nucula on a coral reef in Puerto Rico. In: Rützler K (ed) New perspectives in sponge biology. Smithsonian Institution Press, Washington, DC, p 36-44

Vicente VP (1993) Spongivory in Caribbean hawksbill turtles, Eretmochelys imbricata: data from stranded specimens. In: Schroeder BA, Witherington BE (comps) Proc 13th Annual Symp on Marine Turtle Biology and Conservation. NOAA Tech Memo NMFS-SEFSC-302, Miami, p 185-188

Waddell B, Pawlik JR (2000a) Defenses of Caribbean sponges against invertebrate predators. I. Assays with hermit crabs. Mar Ecol Prog Ser 195:125-132

Waddell B, Pawlik JR (2000b) Defenses of Caribbean sponges against invertebrate predators. II. Assays with sea stars. Mar Ecol Prog Ser 195:133-144

Wiedenmayer F (1977) Shallow-water sponges of the western Bahamas. Experientia Supplementum 28. Birkhäuser Verlag, Basel

Wilkinson CR, Vacelet J (1979) Transplantation of marine sponges to different conditions of light and current. J Exp Mar Biol Ecol 37:91-104

Wulff J (1994) Sponge feeding by Caribbean angelfishes, trunkfishes, and filefishes. In: van Soest RWM, van Kempen TMG, Braekman JC (eds) Sponges in time and space. AA Balkema, Rotterdam, p 267-271

Wulff J (1997) Parrotfish predation on cryptic sponges on Caribbean coral reefs. Mar Biol 129:41-52

Wulff J (2000) Sponge predators may determine differences in sponge fauna between two sets of mangrove cays, Belize Barrier Reef. Atoll Res Bull 477:251-263

Submitted: April 4, 2002; Accepted: August 7, 2002 Proofs received from author(s): November 18, 2002 